\title{
Credit or debit? The effect of issue ownership on retrospective economic voting
}

\author{
Carolina Plescia $^{1} \cdot$ Sylvia Kritzinger ${ }^{1}$
}

Published online: 7 April 2017

(C) The Author(s) 2017. This article is an open access publication

\begin{abstract}
This paper examines issue ownership as a mechanism for understanding how voters' expectations of parties' issue competence impact retrospective voting. On the one hand, issue ownership can represent a stock of credit for parties to draw on, which may help incumbent parties escape punishment for poor performance. On the other hand, prior issue competence associations may set certain expectations in voters' minds. This lends to the idea that parties might be even more severely punished for poor performance when they own the issue. This contribution sets out to test these two propositions. Our results suggest that since voters expect the party to perform well, especially on the issue it owns, positive performance reaps no reward, while negative performance is more severely punished. There are, however, differences across parties, with the chancellor party in government held as the main actor responsible for positive or negative economic developments.
\end{abstract}

Keywords Issue ownership · Retrospective economic voting · Campaign strategies · Voters'expectations

\section{Introduction}

Retrospective voting portrays voters as looking to the past and focusing on what has happened on the incumbent's watch, when evaluating their choices at an election (Fiorina 1981; Key 1966; Kramer 1971; for a review, see Healy and Malhotra

The original version of this article was revised: May 2017. The original was initially published electronically on the publisher's internet portal (currently SpringerLink) on April 7 2017, without open access, but this has since then been amended.

Sylvia Kritzinger

sylvia.kritzinger@univie.ac.at

1 University of Vienna, Rathausstraße 19/1/9, 1010 Vienna, Austria

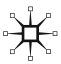


2013). The consideration that voters use elections to hold governments accountable lies at the heart of democratic theory. It is no wonder then that political scientists have spent considerable time investigating the extent to which voters engage in retrospective voting (e.g., Anderson 2000; Duch and Stevenson 2008; Lewis-Beck and Stegmaier 2007; Wilkin et al. 1997). Recent research has made a significant advancement in exploring the micro foundations of retrospective voting behavior (e.g., de Vries and Giger 2014; Duch et al. 2000; Huber et al. 2012; Neundorf and Adams 2016; Singer 2011). Yet, despite the extensive literature on retrospective voting, the question of how voters' expectations condition performance evaluations remains surprisingly understudied (Malhotra and Margalit 2014). Is retrospective voting affected by the expectations set in advance by the parties? In other words, is retrospective voting influenced not only by indicators of performance but also by measures of prior expectations of performance?

In this paper, we examine one important indicator of voters' prior expectations about parties' abilities to handle certain issues: voters' perceived issue ownership. Issue ownership has become an established concept in the literature on party competition and voting behavior since Budge and Farlie (1983) and later Petrocik (1996) introduced the idea that parties have long-standing reputations for competence and the ability of handling certain issues (e.g., Bélanger 2003; De Bruycker and Walgrave 2014; Tresch et al. 2013; Walgrave et al. 2009, 2012). Anderson (1995) indicates that voters should structure credit and blame according to the parties' issue competencies. What then is the role of issue ownership perceptions in shaping voters' assessments of government performance?

One possibility is that issue ownership represents a stock of credit for parties, which can constitute an important factor that helps account for why parties might not be punished for poor performance (Bélanger and Nadeau 2015; Egan 2013; Martinsson 2009). In this case, issue ownership means that a party has saved up credit to draw on, and voters continue to see the party in a positive light. Alternatively, prior issue associations may set certain expectations in voters' minds. This logic extends directly from the seminal work of Powell and Whitten (1993), who argue that voters expect more from a party when that party is perceived as the issue owner. This lends to the idea that the electoral impact of retrospective evaluations may be more severe if parties set high expectations beforehand. This contribution sets out to test these two propositions.

We focus on the economy on which most of the existing literature on retrospective voting has hitherto focused. The economy is almost always a salient issue in modern election campaigns (Vavreck 2009); it is among the top priorities of voters, and parties and candidates agree that the nation's economic well-being is a desired goal. Furthermore, issue ownership has been shown to matter especially concerning such issues that all parties are in favor of, which Stokes (1963) refers to as 'valence issues'.

To this end, we use panel data from the Austrian National Election Study (AUTNES) covering the pre- and post-election setting of the national election held in September 2013, as well as an inter-election wave two years after, in September 2015. These data contain direct individual-level indicators for economic 
evaluations, and questions covering issue ownership were asked consistently across the three panel waves. Given the nature of panel data, we can specify more informative models that incorporate the dynamics of respondents' evaluations, compared to those in past analyses. In the period of investigation, Austria was governed by a two-party grand coalition, comprised a left-wing and a right-wing party with diverging reputations for issue competence (Mair et al. 1999). Hence, an examination of interaction between rival incumbent parties that have a different history of issue ownership is possible. In this paper, we do not focus solely on vote choice for the incumbent as a collective actor but examine the coalition partners separately (see also Williams et al. 2015).

Our results suggest that retrospective evaluations affect ballot choices differently when the party is considered to own the issue. In particular, we find that prior issue associations inevitably set high expectations in voters' minds, with poor performance being more severely punished. The effect is particularly strong for the chancellor party, when compared to the junior coalition partner.

\section{Issue ownership and retrospective voting: the story so far}

The idea behind retrospective voting is rather straightforward: voters assess parties based on their earlier achievements and these retrospective evaluations of parties' past performances enter a voter's decision-making process. A plethora of studies have investigated retrospective voting, focusing primarily on the economy (e.g., Anderson 2000, 2007; Healy and Malhotra 2013; Lewis-Beck and Stegmaier 2000). While issue priorities vary substantially between voters and electoral contexts (Singer 2011), economic problems, such as unemployment, are typically among voters' most pressing concerns (Duch and Stevenson 2008). Empirical analyses regularly find that 'when economic conditions are bad, citizens vote against the ruling party’ (Lewis-Beck 1991, p. 2).

There is, however, increasing evidence that retrospective voting does not apply equally to all citizens of a polity. Duch et al. (2000) demonstrate that public evaluations of the national economy vary systematically with information, media exposure, political attitudes, personal experiences, and demographic characteristics. De Vries and Giger (2014) stress the impact of political information and the saliency attached to specific issues.

A surprisingly understudied question within the retrospective voting literature is how voters' expectations condition performance evaluations (Malhotra and Margalit 2014; Neundorf and Adams 2016). While it is clear that the re-election prospects of incumbents are harmed by bad outcomes in the past and, albeit to a lesser extent, sustained by good outcomes (Mueller 1970; Nannestad and Paldam 1997, 2002), it is still unclear to what extent retrospection is affected by the expectations voters have in advance. Is the electoral impact more severe for a party if voters have high expectations of the performance for that party that owns the issue? Put more formally, should models predicting an incumbent's re-election, besides including indicators of performance, also include measures of prior expectations of performance? In 
this paper, we focus on voters' perceived issue ownership as a mechanism for understanding how voters' prior expectations impact retrospective voting. ${ }^{1}$

The issue ownership concept has become widely used in the literature on both party competition (e.g., Green-Pedersen 2007; Walgrave and De Swert 2007) and electoral behavior (e.g., Bélanger and Meguid 2008; Green and Hobolt 2008; Meyer and Müller 2013; Van der Brug 2004). Research has shown that issue ownership has an associative and a competence component (Walgrave et al. 2012). The latter component is inevitably linked to the performance of parties in their handling of the specific problems, and existing studies show that government performance has a strong effect on issue ownership (e.g., Bellucci 2006; De Bruycker and Walgrave 2014; Stubager and Slothuus 2013). Recent studies make a strong case that issue ownership can also play a role in retrospective voting, with parties' issue competence structuring voters' credit and blame attributions (Anderson 1995; Egan 2013; Martinsson 2009). In this regard, issue ownership functions as a yardstick for comparison for voters which helps them evaluate government economic performance. This links to the general idea of voters' need for comparisons and the numerous studies which demonstrate that voters systematically compare policy outcomes across time (Palmer and Whitten 1999) as well as across borders (Kasper et al. 2016; Kayser and Peress 2012).

The few existing studies that directly examine the effect of issue ownership on retrospective voting suggest that an incumbent who owns an issue enjoys a reputational advantage that will allow the incumbent to get re-elected even if confronted with a bad economy. This advantage can come from the party's history of issue attention and from its past performance (Anderson 1995; Bélanger and Gélineau 2010; Bélanger and Nadeau 2014; Martinsson 2009). In this case, issue ownership means that a party has saved up credit to draw on, and voters continue to see the party in a positive light. Bélanger and Nadeau (2015) refine this argument and explain that issue ownership may cause voters to view the evolution of economic conditions in a comparative perspective. According to this framework, despite negative economic evaluations, issue ownership leads voters to believe that the economic situation is better than elsewhere, leading to government support even after a mediocre or bad performance. Positive economic evaluations instead will simply reinforce the positive effect of issue ownership on vote choice. However, not being perceived as the issue owner may prevent an incumbent from benefiting from a strong economy because voters may think that the economy is even better elsewhere, while a bad economy with no issue ownership instead may lead to an even stronger negative impact of retrospective voting.

Based on these works, it is to be expected that issue ownership functions as a stock of credit for the incumbent that will either reinforce the positive effect of positive economic evaluations on vote choice or reduce the negative effect of

\footnotetext{
${ }^{1}$ Issue ownership is both an aggregate- and individual-level phenomenon. In this study, we are primarily focused on the individual level. Averaging these perceptions across voters provides us with an overall picture of how a party is perceived. However, whether a voter thinks there is an issue owner depends on his or her individual pattern of competence perceptions (Wagner and Meyer 2015). This means that perceptions of issue ownership should not just reflect general attitudes toward that party (see also the discussion in Egan 2013).
} 
negative economic evaluations (see also Green and Hobolt 2008). Meanwhile, the lack of issue ownership means either no effect at all or a greater (lower) negative (positive) effect in bad (good) economic conditions. The first set of hypotheses, derived from the existing literature, reads as follows:

Hypothesis 1a Positive economic evaluations have a higher positive effect on the vote for the incumbent when the incumbent is tied to the issue.

Hypothesis 1b Negative economic evaluations have a lower negative effect on the vote for the incumbent when the incumbent is tied to the issue.

A contending view stresses that prior issue associations may actually work to a parties' disadvantage, given that certain high expectations are set in voters' minds. Already Powell and Whitten (1993) argued that voters expect more from a party when that party owns a certain issue. Specifically, voters expect left-wing parties to deal better with unemployment and short-term economic stimulation, while they expect right-wing parties in government to deal better with inflation (Duch and Stevenson 2008; Narud and Valen 2008). Consequently, left-wing parties are likely to gain votes in times of a decreasing unemployment rate, while right-wing parties particularly benefit from falling inflation rates (Parker 1986; see also Van der Brug et al. 2007). Thus, when voters assess governments retrospectively and judge their performance in office, they might well hold left-wing parties to a higher standard on unemployment and be less concerned about inflation, and vice versa for right-wing parties (Narud and Valen 2008; Powell and Whitten 1993). Findings on party campaign strategies seem to lend support to this argument. In fact, while the saliency theory expects parties to emphasize the issue they own during the election campaign (e.g., Budge and Farlie 1983; Dolezal et al. 2014; but see also Wagner and Meyer 2014), existing studies find parties' strategies to be influenced not only by their ideology but also by their record. For instance, Winkler and Praprotnik (2015) show that in times of a high unemployment rate, left-wing incumbents, despite owning the unemployment issue, are less likely to refer to their record on this issue.

Following this logic, while an issue owner has the strongest prior reputation, this party also holds the highest expectations to deliver on the issue (see also Seeberg 2015). Since an issue evaluation reflects the difference between expectations of the party and its actual track record, high expectations may actually hurt the issue owner. In an unfavorable context, issue ownership can hence lead voters to punish the party even more, whereas in a favorable context, voters will not reward success, as they will tend to think that the party has simply performed well in an area it has high competence. Meanwhile, not being the issue owner may allow one to get away with a bad economic situation: since voters hold low expectations for a party that does not own the issue, they might conclude the incumbent did a decent job despite a bad economy. We thus formulate our second set of hypotheses as follows:

Hypothesis 2a Positive economic evaluations have a lower positive effect on the vote for the incumbent when the incumbent is tied to the issue.

Hypothesis 2b Negative economic evaluations have a greater negative effect on the vote for the incumbent when the incumbent is tied to the issue. 
Table 1 Hypotheses and expectations

\begin{tabular}{llll}
\hline Performance evaluations & Issue & $\begin{array}{l}\text { Expectations (H1a; H1b) } \\
\text { Issue ownership as credit }\end{array}$ & $\begin{array}{l}\text { Expectations (H2a; H2b) } \\
\text { Issue ownership as debit }\end{array}$ \\
\hline $\begin{array}{l}\text { Negative } \\
\text { Negative }\end{array}$ & Owned & Lower negative effect & Greater negative effect \\
Positive & Not owned & No (or greater negative) effect & Lower negative effect \\
Positive & Owned & Greater positive effect & Lower positive effect \\
\hline
\end{tabular}

Table 1 summarizes the converse expectations on the interaction between economic evaluations and issue ownership derived from the literature that we set up to test in this paper.

We do expect differences across parties in government. Albeit performance voting will not be absent in multiparty coalitions (Duch and Stevenson 2008), the literature has shown that not all incumbent parties are affected equally by retrospective voting (Debus et al. 2014; Plescia and Kritzinger 2016; Plescia forthcoming). We will thus not treat the government as a unitary actor, but test our hypotheses at the party level, taking into account the performance evaluations of and ownership attribution to the various coalition parties. Evidence from economic voting suggests that voters often identify the largest party (or the prime minister's party) as the leading party within the coalition, and thus most in charge of decision making (Anderson 2000; see also Hobolt et al. 2013). Hence, also the credit or blame of issue ownership should be distributed unevenly in a coalition government with the effect of our contending hypotheses being strongest for the leading party within the coalition.

\section{Data and methods}

An individual-level empirical test of the two competing hypotheses should take into account the dynamic structure of the theoretical mechanisms just discussed. Indeed, we need to distinguish between voters who think that a party has a specific reputation at time $t-1$ and ask the same voter to evaluate-in terms of retrospective evaluations - that party at time $t$. Panel observations will allow us to temporally define reputation prior to record assessment and vote choice to avoid possible reciprocal causation based on the fact that, at any given time, judgments on performance and judgments on competence can influence each other (Bélanger and Meguid 2008; Bélanger and Nadeau 2015).

In this paper, we therefore use data from a three-wave panel study conducted as part of the Austrian National Election Study (AUTNES) (Kritzinger et al. 2016). The AUTNES panel data covers the national election of 2013 (pre-electoral wave (wave 1) and post-electoral wave (wave 2)) and one non-election year in 2015 (wave 3$)^{2}$ This rich individual-level data allows us to parse out the reciprocal

\footnotetext{
2 The initial pre-electoral survey (wave 1) was conducted from 5 August to 27 September 2013, using Computer-Assisted Telephone Interviews (CATI) with a total sample size of 4011 respondents. $65 \%$ of the respondents were re-interviewed after the national election took place in September 2013 (wave 2).
} 
causation between issue ownership and retrospective assessment on vote choice by providing us with temporally dependent observations. All variables we use below, i.e., economic evaluations and issue ownership, have been asked in all three waves. Our study represents one of the first attempts to disentangle the important relationship between prior issue ownership association and retrospective voting.

In the period of investigation, Austria was governed by a two-party coalition. The two government parties are the Social Democratic Party of Austria (SPÖ) and the Austrian People's Party (ÖVP). The center-left party, the SPÖ, historically represents the workers/secular/urban group, while the center-right party, the ÖVP, still considers itself the representative of the opposite groups (Kritzinger et al. 2013). They formed a grand coalition after the general election in 2013 with the SPÖ, obtaining around $2 \%$ more votes than the ÖVP, holding the chancellorship. The two parties have a different history of issue ownership. While the center-left SPÖ is considered the most competent party on employment issues and welfare provisions, the center-right coalition partner ÖVP has a long-standing reputation on economic issues such as industry, small- and middle-sized enterprises, and deregulation (Mair et al. 1999; Winkler and Praprotnik 2015). Consequently, the ÖVP controls the economics and the finance ministry, while the SPÖ heads the social ministry. During the time of investigation, Austria experienced increasing unemployment rates. While after the outbreak of the financial and economic crises in 2008, the Austrian economy remained rather stable, unemployment figures have been rising continuously since 2013, reaching an all-time high of almost $10 \%$ of unemployed people in 2016. ${ }^{3}$ Hence, on several dimension, Austria constitutes an ideal case to examine whether economic competence expectations can shape voters' assessments of government parties' economic performances: turbulent economic circumstances and two parties with different histories of issue ownership forming a coalition.

Our dependent variable 'party choice' measures intended vote choice in 2015 using the following question: 'If national elections were to take place next Sunday, which party do you think you would vote for?' 4

Turning to our first independent variable, retrospective evaluations, often, national election studies ask respondents, 'How do you think the government has handled the economy in the last 4 years?' This wording appears to inflate the relationship between performance evaluations and issue ownership perceptions by virtue of the strong cue entailed in framing the question around the conduct of the

Footnote 2 continued

The 2015 RCS Inter-Election Panel Survey (panel component, wave 3) was again conducted using CATI from 14 August to 20 October 2015. The total sample size for the RCS Inter-Election Panel Survey is $n=1223$ (30.5\% re-interviewed from wave 1$)$.

3 The degree of retrospective voting is likely to differ as a function of the saliency that voters attach to a given policy area (Bélanger and Meguid 2008; De Vries and Giger 2014). Given that the majority of our respondents regarded either the economy or unemployment as an important issue in 2015, and thus little variation on issue salience is provided, we cannot test the conditional impact of salience on issue ownership in this paper. Future research might consider paying particular attention to this conditional impact.

4 Vote intention in national elections is commonly used as the dependent variable in studies of economic voting (e.g., Anderson 2000; Duch and Stevenson 2008; Hobolt et al. 2013; Nadeau et al. 2002). 
government, which could increase partisan reasoning (Mondak 1993; Slothuus and de Vreese 2010; Van der Brug 2004). An arguably better indicator is what Stubager and Slothuus (2013) term an 'un-cued question', now more commonly employed in comparative research, asking respondents 'What would you say: Has the economic situation in Austria over the past twelve months got better, stayed the same or got worse?' (the five response categories range from 'Much better' to 'Much worse'). We measure retrospective evaluation in $2015(t)$, using this question. About $53.6 \%$ of the respondents claimed that the economic situation stayed the same, $14.3 \%$ that it got better and $32.2 \%$ that the situation got worse. ${ }^{5}$

When it comes to issue ownership, the literature has relied on several different measurements in voter surveys (Walgrave et al. 2015). Most approaches measuring ownership ask respondents to assess which party would be best able to handle or solve a specific issue or problem (e.g., Petrocik 1996; Stubager and Slothuus 2013). Another frequently used question asks survey participants to state who they trust more to do a good job on a given issue (e.g., Egan 2013; Holian 2004). These studies ask about a party's competence on a political issue. We follow this approach in our study and capture issue ownership using the question: 'If you think back to the election campaign, which party made the best proposals about the following issues in the campaign? ${ }^{6}$ In this paper, we discuss responses on two topics related to the economy: 'tackling the financial and Euro crises' and 'tackling unemployment'.

While we are primarily interested in the conditional impact of issue ownership, we need to control for additional factors that we know have a strong effect on vote choice. First and foremost, we control for partisanship, as it can potentially bias our estimates of performance voting (Duch and Stevenson 2008; Evans and Andersen

\footnotetext{
5 To capture party performance evaluations on specific policy domains, we also run analyses on the following questions: 'How satisfied or dissatisfied are you with the performance of party X on [ITEM] in the past two years? Please indicate your answer on the scale from -5 to +5 .' The items include 'the stimulation of the economy' and 'the fight against unemployment'. Results taking this explicit party performance evaluation into account are similar in terms of direction to the un-cued question but are not always statistically identical. This might be due to a strong correlation between party preferences and party performance.

6 This question refers to the quality of recent 'proposals' rather than to handling abilities, an approach commonly followed in previous research (though see Aalberg and Jenssen 2007; Green and Hobolt 2008 and Lachat 2014; Walgrave et al. 2015). We decided on this question wording based on cognitive pretesting (Wagner and Zeglovits 2014), which showed that respondents struggled less when asked about 'proposals' than when asked about the party 'best/worst at dealing with issue X,' perhaps because thinking about past actions is more concrete than considering hypothetical handling abilities. As discussed by Wagner and Meyer (2015), one concern is that referring to proposals means that we are partly capturing positional as well as competence assessments. However, the cognitive interviews also indicated that all questions that measure issue competence, irrespective of question wording, contain significant reasoning in terms of policy preferences (Wagner and Zeglovits 2014). Beside this, tests carried out by Wagner and Meyer (2015) show that between 74 and $84 \%$ of respondents name identical parties in both questions, 'best proposals' and 'best able to handle.' This suggests that the two questions do measure the same concept. Indeed, we obtain similar results for both measures.

7 The results we discuss below are almost identical if we measure issue ownership in wave $1(t-2)$. Recall that we measure issue ownership at time $t-1$ (wave 2) and economic evaluations at time $\mathrm{t}$ (wave 3 ) to avoid possible causation between issue competence and retrospective evaluations. Additional tests we performed, however, indicate that while party issue ownership acts somewhat as a bias in parties' evaluations, its effect is rather small. As Petrocik (1996) noted, the indicator of issue competence is correlated with partisanship, while not being a pure reflection of it (see also Bélanger and Meguid 2008).
} 
2006). Partisanship effect is measured in wave 1 to minimize a possible problematic effect of partisanship on performance evaluations, as voters who feel close to a political party are likely to evaluate its performance more positively through a 'partisan lens' (Wagner and Meyer 2015). ${ }^{8}$ We also control for a number of demographic control variables in the form of age, gender, and income, as well as respondents' political interest and political ideology in the form of distance between the voter and the party supported at the elections. All control variables are measured in wave $1(t-2){ }^{9}$

\section{Empirical findings}

We start our foray into the analysis by looking at how many respondents positively tied the different parties to the two economic issues in the panel survey. As Fig. 1 shows, the party most often associated with tackling the financial and economic crises was the second largest party in the government, the ÖVP; among the remaining parties, the SPÖ comes second, followed by the opposition parties, the Greens and the radical right Austrian Freedom Party (FPÖ). Moving to unemployment, there is a clear issue ownership advantage for the largest party in government, the SPÖ. When it comes to the second party named most commonly as having the best proposal on how to 'fight unemployment,' the ÖVP is named, followed again by the two parties in the opposition. Both perceived issue ownerships to a large extent reflect the long-standing issue competence reputation of the two government parties.

We then estimate a series of separate logit regression models where the dependent variable is a dummy variable with vote choice for one of the two incumbent parties. Thus, in the model for the SPÖ, the dependent variable indicates whether a respondent today would vote for the SPÖ or not $(1=$ yes, $0=$ no $)$. We run then the same model for the ÖVP. To facilitate the discussion of the results and link them directly to our hypotheses (see Table 1), we dichotomize the performance evaluation variables and include a positive and a negative evaluation dummy.

In a first step, we look at the two main independent variables separately (Models 1 and 5 for the SPÖ, and Models 3 and 7 for the ÖVP in Table 2). Starting with the SPÖ and voters' economic evaluations, Model 1 and Model 5 indicate that an overall negative economic performance evaluation hurts the incumbent chancellor party. In other words, the more negative the economy is evaluated by voters, the less likely they are to vote for the SPÖ. However, positive evaluations do not consistently increase the chances of a SPÖ vote. These results are consistent with part of the economic voting literature that has occasionally suggested that the retrospective response of the electorate is asymmetric with voters punishing more

\footnotetext{
${ }^{8}$ Results are almost identical if we measure partisanship and economic evaluations in the same wave.

9 While multinomial logit models would also be an option to test our hypotheses, we opt for binary logit models in which one party is focused upon at time because it allows us to test our hypotheses more directly. In fact, our hypotheses do not specify a reference (voting) category, but put forward expectations on the conditional impact that owning versus not owning the issue has on the relation between economic evaluations and vote choice. Yet, Table A1 in the Appendix shows that using multinomial logit models lead to substantially similar conclusions.
} 


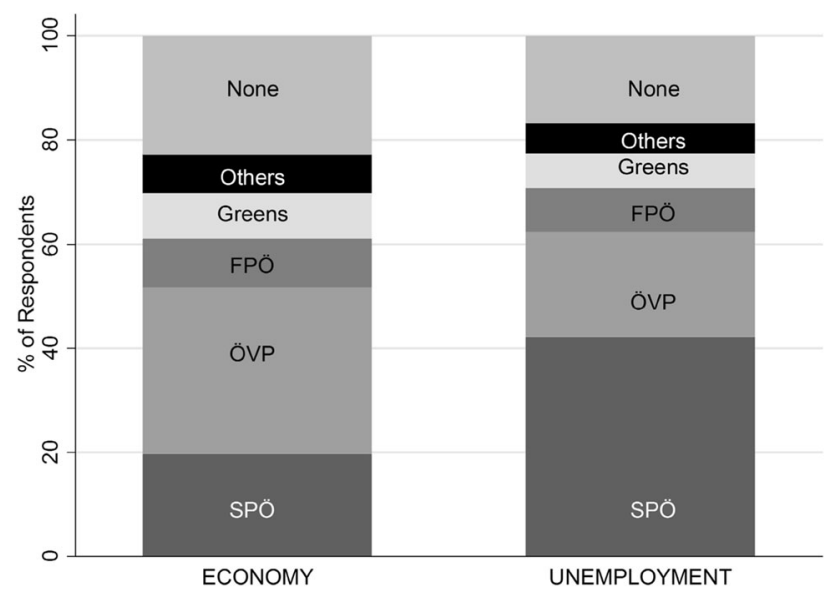

Fig. 1 Party with best proposals for economy and unemployment (wave 2)

than they reward (Mueller 1970; Nannestad and Paldam 1997, 2002). The story is slightly different for the ÖVP: in Model 3 and Model 7, we see that negative perceptions of the economy hurt the junior coalition partner, albeit not as strongly as the SPÖ. The ÖVP, however, benefits from positive economic perceptions. In other words, positive perceptions of the economy only help the center-right incumbent, the ÖVP.

Turning to issue ownership, for both parties, issue ownership has a positive effect on voting for that party. The positive effect of issue ownership is strong and consistent across all models, both when we consider issue ownership on unemployment and the handling of the financial and economic crises.

Our hypotheses postulate an interaction effect between economic evaluations and issue ownership. The second set of models in Table 2 present the results when an interaction is added between each economic evaluation, positive and negative, and the issue ownership variable. In line with Hypothesis 1a and Hypothesis $1 \mathrm{~b}$, we would expect to find two positive interaction effects: if the incumbent party is the issue owner, then economic evaluations should have a greater positive effect (or a lesser negative effect) on the incumbent vote choice than if the incumbent party is not the issue owner. On the contrary, in line with Hypothesis 2a and Hypothesis 2b, we would expect to find two negative interaction effects: if the incumbent party is the issue owner, then economic evaluations should have a greater negative effect (or a lesser positive effect) on the incumbent vote choice than if the incumbent party is not the issue owner.

Starting with the SPÖ, results in Table 2 reveal two negative interaction terms across all sets of models, a result that would support the set of Hypotheses 2. For example, take the results of Model 2 in Table 2 which refers to the main incumbent party for the issue of unemployment. The coefficients indicate that a positive economic evaluation has a positive impact $(+0.88)$ on voting for the incumbent party when the latter does not own the unemployment issue, and an negative impact when it is perceived as the issue owner $[+0.88+(-1.21)=-0.33]$. Similarly, a 


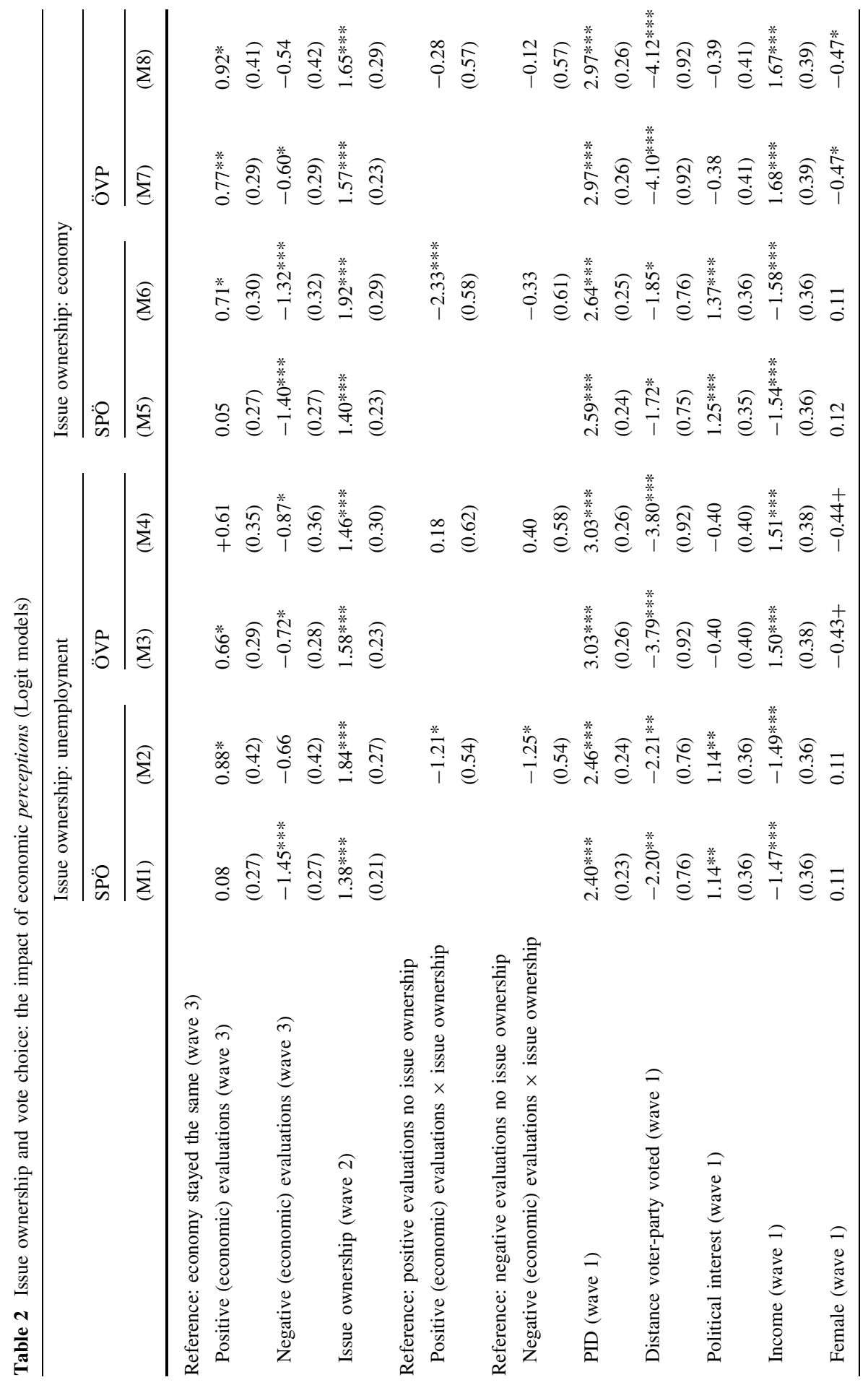




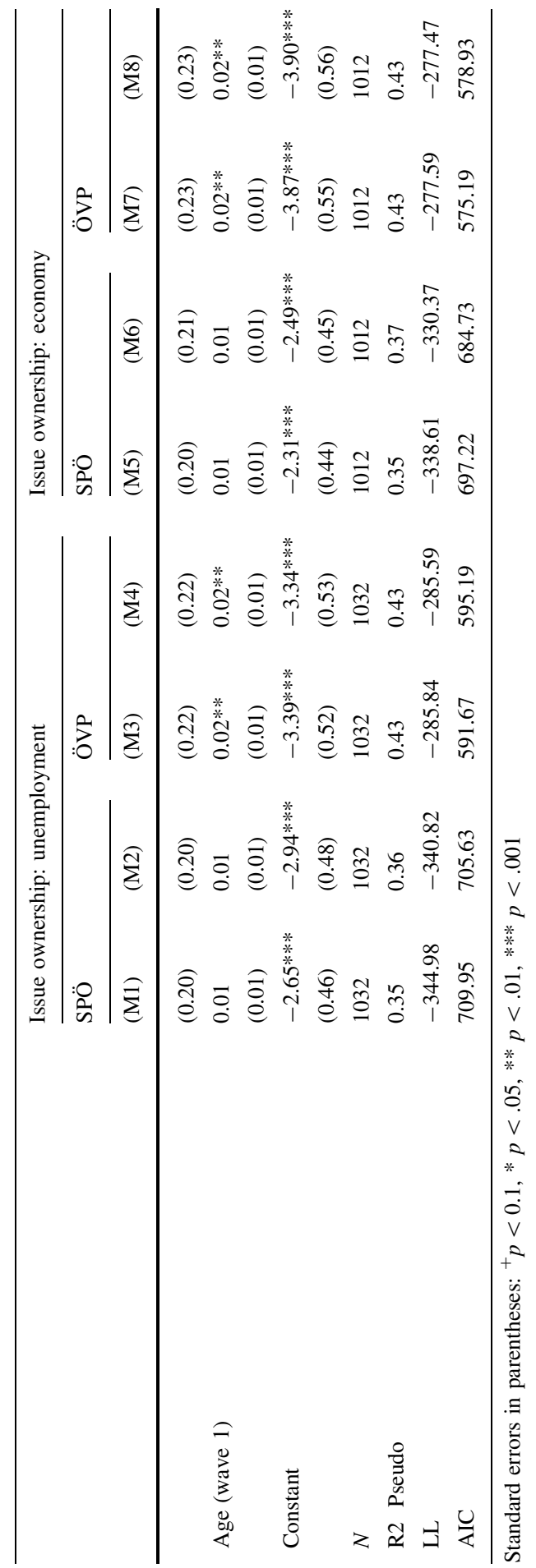


negative assessment of the national economic condition has a negative impact (-0.66) on voting for the incumbent party when the latter does not own the unemployment issue and an even much stronger negative impact when perceived as the issue owner $[-0.66+(-1.25)=-1.91]$. For the SPÖ, we thus find that perceived issue ownership on unemployment, on the one hand, leads to overall negative effects in case of positive evaluations, and on the other hand, leads to greater negative effects in case of negative performance evaluations. Moving to the junior coalition partner, in the models for the ÖVP, Table 2 reports consistent nonsignificant coefficients. In short, we find support for Hypotheses $2 \mathrm{a}$ and $2 \mathrm{~b}$ across all models for the chancellor party, but no effect for the junior coalition partner, nor for the financial and economic crises issues.

To facilitate the interpretation of the results further, we show the marginal effect of the interaction terms on the predicted probability of voting for either the SPÖ or the ÖVP. All remaining covariates are held constant at their mean (continuous variables) or mode (dichotomous variables).

Figure 2 shows the estimated marginal effect of perceived issue ownership of unemployment on the probability of voting for one of the two incumbent parties. We can observe graphically that positive economic evaluations have no positive effect on the vote for the chancellor party, when the party is tied to the issue, but rather result in no reward. Similarly, negative economic evaluations have a greater negative effect on the vote for the SPÖ when the party is perceived as the issue owner when compared to when it is not perceived to be the issue owner. This is particularly the case for perceived issue ownership on unemployment. For the junior coalition partner, the ÖVP, we cannot see any difference between being perceived as the issue owner or not. While the positive marginal effects on both economic issues are positive, and hence seem to suggest that a positive evaluation reinforces

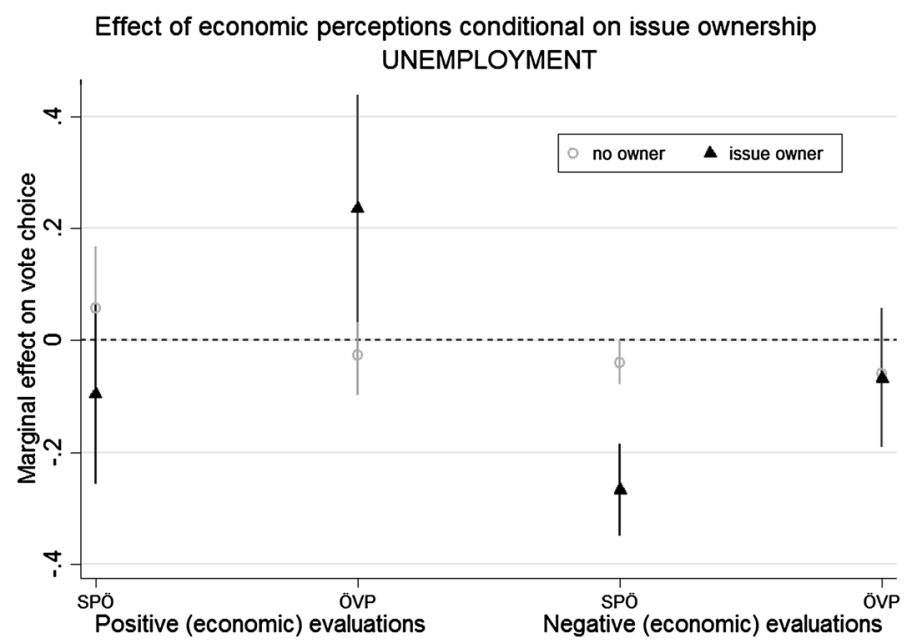

Fig. 2 Issue ownership (unemployment) and vote choice: the impact of economic evaluations. Note This figure shows the estimated marginal effect of issue ownership on the probability of incumbent voting by economic perceptions. Estimates based on Table 2 Model 2 and Model 4 


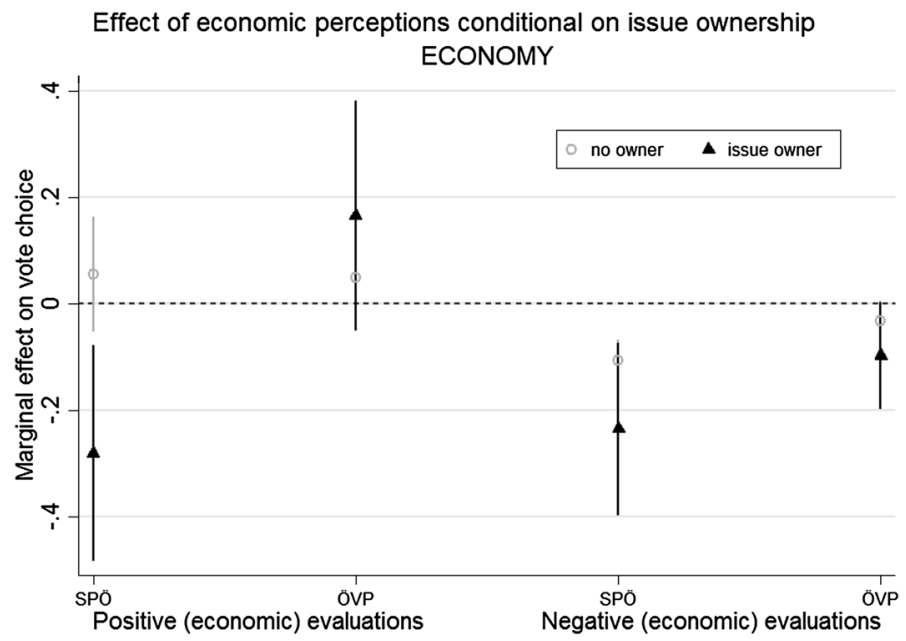

Fig. 3 Issue ownership (economy) and vote choice: the impact of economic evaluations. Note This figure shows the estimated marginal effect of issue ownership on the probability of incumbent voting by economic perceptions. Estimates based on Table 2 Model 6 and Model 8

vote choice if the ÖVP is the issue owner, the results are not statistically significant. Hence, it is only the case of the chancellor party for which we can state that issue ownership appears to set high expectations in the minds of voters, and as they expect the party to perform well on the issue, positive performance does not get rewarded, while negative performance gets more severely punished.

Turning to the estimated marginal effect of issue ownership on handling the financial and economic crises, in Fig. 3, we observe very similar patterns as for unemployment, albeit this time the results are less strong. Again, it is the chancellor party that is affected by greater negative effects if the performance evaluations are negative, though the results are not significantly different compared to when not owning the issue. Positive performance evaluation exerts no positive effect when being the issue owner (confirming again $\mathrm{H} 2 \mathrm{a}$ ), but rather no reward at all. ${ }^{10}$ Hence, the negative effect for the SPÖ is consistent across all models. Again, we find nonsignificant results for the junior coalition partner, the ÖVP, although the marginal effects suggest that the ÖVP vote overall benefits from positive evaluations and is punished by negative ones.

Overall, we can conclude that retrospective voting is affected by issue ownership; however, an effect can only be observed for the chancellor party. The effect of issue ownership on performance voting is hence distributed unevenly in a coalition government with the chancellor party obtaining either less or no reward or being punished more severely (see also van der Brug et al. 2007). This holds for both ownership on the economy in general and unemployment in particular. Issue

\footnotetext{
${ }^{10}$ While Fig. 3 indicates that positive economic evaluations lead to punishment if the SPÖ is considered the issue owner of the economy, this result needs to be interpreted cautiously due to the very low number of respondents which consider simultaneously that the economy has improved and that the SPÖ is the issue owner of the economy $(n=34)$.
} 
ownership does not prevent the incumbent from getting punished, but it is rather the opposite: Prior issue associations set certain expectations in voters' minds with good (poor) performance of the chancellor party less (more) markedly rewarded (punished). ${ }^{11}$

\section{Conclusions}

According to the retrospective voting theory, voters' decisions are determined by the parties' record (Fiorina 1981). On Election Day, rational voters hold incumbents accountable for their past performance-if voters are satisfied with the government's record, they are likely to reward it, while a performance that fails to meet voters' standards jeopardizes re-election (Fearon 1999). If voting decisions are shaped by the record, parties have an incentive to prime voters with regard to it. However, voters' prior issue associations mediate the effect and the power retrospective evaluations have on vote choice.

In this paper, we have offered a valuable framework for documenting how issue ownership and retrospective evaluations affect ballot choice. Two contending expectations have been put forward by the literature. On the one hand, issue ownership can represent a stock of credit for parties to draw upon (Bélanger and Nadeau 2015; Egan 2013; Martinsson 2009). On the other hand, prior issue associations can set certain expectations in voters' minds. This lends to the idea that parties might be even more severely punished for poor performance when they own a certain issue. The evidence provided in this paper supports the second claim that issue owners will actually suffer from negative evaluations, as high expectations with regard to issue solving are connected to it. Parties tied to the economy tend to be more severely punished in times of negative economic developments and also reap less reward in case of positive evaluations.

Our results are strong when it comes to the chancellor party, but no effect was detected for the junior coalition partner. This is particularly the case for the unemployment issue, where increased saliency reinforces the effect for the left-wing senior coalition partner. The debit of issue ownership is thus distributed rather unevenly in a coalition government, which lends to the idea that voters have different expectations on coalition partners' ability and responsibility to deliver on economic issues. We can thus contribute to a very recent literature on this matter (e.g., Debus et al. 2014; Williams et al. 2015) by arguing that if the senior partner is the issue owner, this has rather negative effects on the incumbent, regardless of whether the economic perceptions are negative or positive, while the electoral accountability of the junior partner seems to not be conditional on whether it is considered the issue owner. The results in this study thus offer important insights into retrospective voting mechanisms for parties who serve at different levels of coalition governments. Because the chancellor in Austria has rather low

\footnotetext{
11 Measuring vote choice in 2013 instead of 2015 leads to results substantially similar to those presented in the paper. As discussed in the paper, to avoid endogeneity concerns that prior expectations may themselves be influenced by retrospective evaluations or vote choice, we opt for the model measuring vote choice in 2015 .
} 
competencies in terms of setting the (policy) agenda in the cabinet, the effect of punishing the prime minister's party, relative to other coalition partners, might even be stronger in countries like the United Kingdom and Germany where the prime minister has a very strong position in terms of decision making in the cabinet and/or agenda setting.

While our analyses are individual in nature, we have remarks for party politics more generally and parties' campaign strategies in particular. While saliency theory expects parties to emphasize the issue they own during the election campaign (e.g., Budge and Farlie 1983; Dolezal et al. 2014; but see also Wagner and Meyer 2014), the evidence provided in this paper suggests that in electoral campaigns, it makes sense for parties to de-emphasize issues they own if the performance is mediocre or negative, as voters will punish parties on these issue even more severely. Hence, our study indicates which issues parties emphasize or should emphasize derives not only from their competence but also from their performance, as voters take both of these aspects into account when casting a vote. Issue ownership is by no means a protective shield that reduces vote losses in times of crisis. Consequently, in times of crisis especially, it may be beneficial for parties not to win control over certain cabinet portfolios that would lead them to disappoint voters' expectations given the party's ideological profile.

Future studies should devote careful attention to the conditional impact that expectations play on citizens' willingness and competence to evaluate the performance of incumbent parties. This relates to the general idea, often neglected in the literature, that voters use yardsticks when evaluating political objects.

Acknowledgements This work is supported by the Austrian National Election Study (AUTNES), a National Research Network (NFN) sponsored by the Austrian Science Fund (FWF) [S10902-G11]. We are grateful to Mary Stegmaier, Markus Wagner and the participants to the 2016 Midwest Political Science Association conference for feedback on an earlier version of this manuscript. We also thank the anonymous reviewers for their critical comments and suggestions, which have greatly improved this paper.

Open Access This article is distributed under the terms of the Creative Commons Attribution 4.0 International License (http://creativecommons.org/licenses/by/4.0/), which permits unrestricted use, distribution, and reproduction in any medium, provided you give appropriate credit to the original author(s) and the source, provide a link to the Creative Commons license, and indicate if changes were made.

\section{Appendix}

See Table 3. 


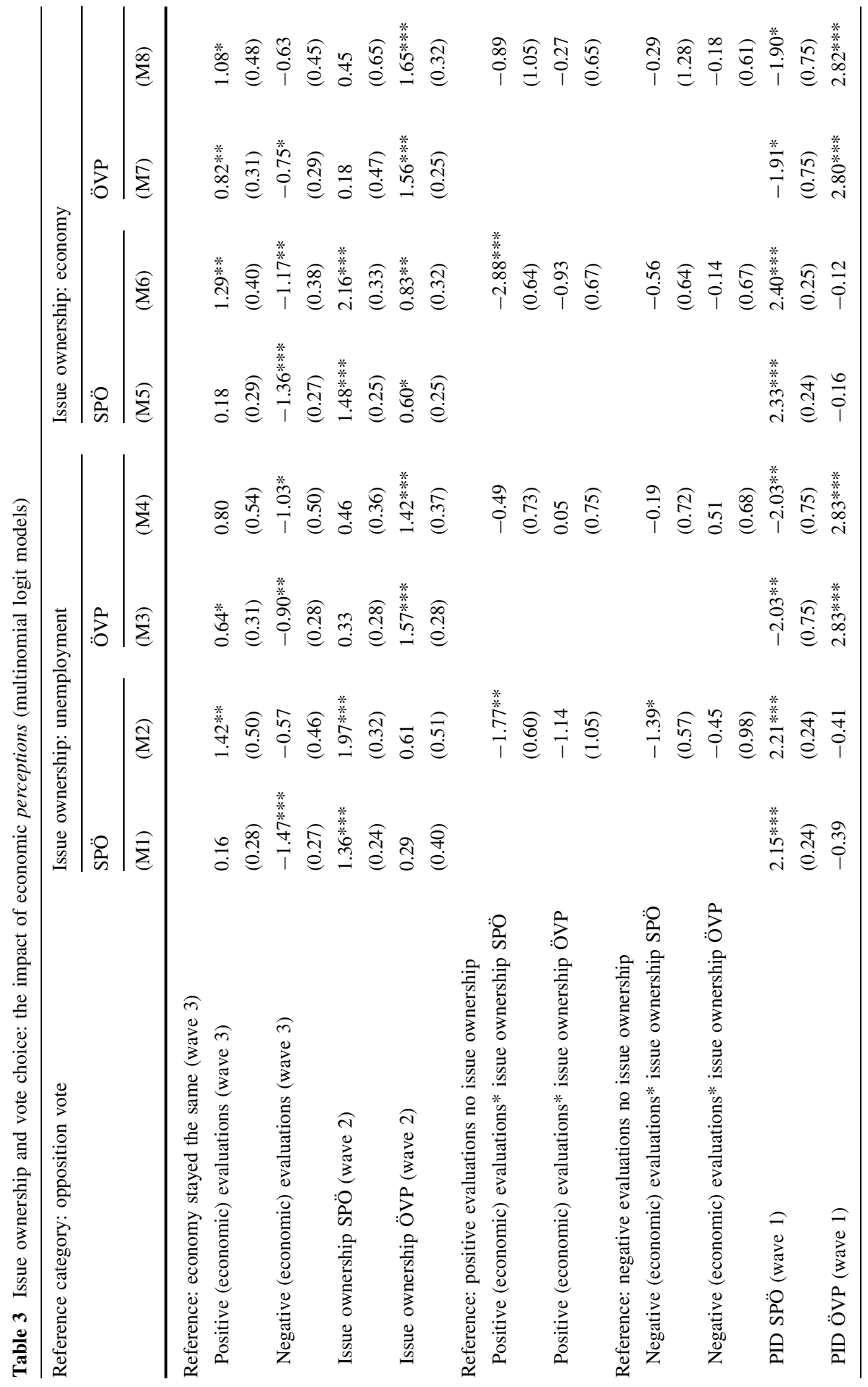




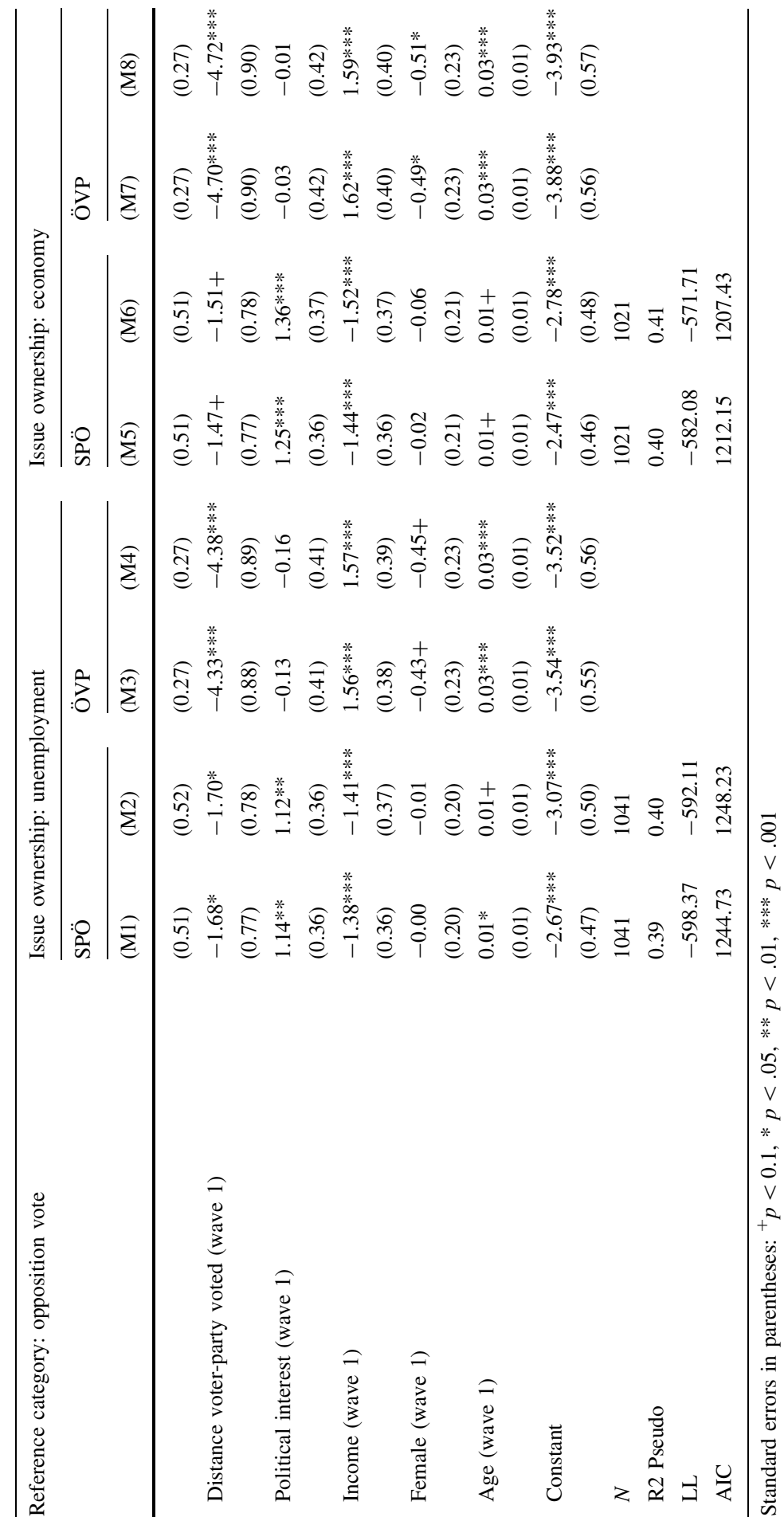




\section{References}

Aalberg, Toril, and Anders Todal Jenssen. 2007. 'Do television debates in multiparty systems affect viewers? A quasi-experimental study with first-time voters'. Scandinavian Political Studies 30 (1): 115-135.

Anderson, Christopher. 1995. Blaming the Government: Citizens and the Economy in Five European Democracies. Armonk, NY: M.E. Sharpe.

Anderson, Christopher J. 2000. Economic voting and political context: a comparative perspective. Electoral Studies 19 (2): 151-170.

Anderson, Christopher J. 2007. 'The end of economic voting? Contingency dilemmas and the limits of democratic accountability'. Annual Review of Political Science 10: 271-296.

Bélanger, Éric. 2003. Issue ownership by Canadian political parties 1953-2001. Canadian Journal of Political Science 36 (3): 539-558.

Bélanger, Éric, and Bonnie M. Meguid. 2008. 'Issue salience, issue ownership, and issue-based vote choice'. Electoral Studies 27 (3): 477-491.

Bélanger, Éric, and François Gélineau. 2010. 'Does perceived competence matter? Political parties and economic voting in canadian federal elections'. Journal of Elections, Public Opinion \& Parties 20 (1): 83-101.

Bélanger, Éric, and Richard Nadeau. 2014. Economic crisis, party competence and the economic vote. Acta Politica 49 (4): 462-485.

Bélanger, Éric, and Richard Nadeau. 2015. Issue ownership of the economy: Cross-time effects on vote choice. West European Politics 38 (4): 909-932.

Bellucci, Paolo. 2006. Tracing the cognitive and affective roots of 'party competence': Italy and Britain, 2001. Electoral Studies 25 (3): 548-569.

Budge, Ian, and Dennis J. Farlie. 1983. Explaining and Predicting Elections: Issue Effects and Party Strategies in Twenty-three Democracies. London: Allen \& Unwin.

De Bruycker, Iskander, and Stefaan Walgrave. 2014. How a new issue becomes an owned issue. Media coverage and the financial crisis in Belgium (2008-2009). International Journal of Public Opinion Research 26 (1): 86-97.

Vries, De, E. Catherine, and Nathalie Giger. 2014. 'Holding governments accountable? Individual heterogeneity in performance voting'. European Journal of Political Research 53 (2): 345-362.

Debus, Marc, Mary Stegmaier, and Jale Tosun. 2014. Economic voting under coalition governments: Evidence from Germany. Political Science Research and Methods 2 (1): 49-67.

Dolezal, Martin, Laurenz Ennser-Jedenastik, Wolfgang C. Müller, and Anna Katharina Winkler. 2014. How parties compete for votes: A test of saliency theory. European Journal of Political Research 53 (1): 57-76.

Duch, Raymond M., and Randolph T. Stevenson. 2008. The Economic Vote: How Political and Economic Institutions Condition Election Results. Cambridge: Cambridge University Press.

Duch, Raymond M., Harvey D. Palmer, and Christopher J. Anderson. 2000. Heterogeneity in perceptions of national economic conditions. American Journal of Political Science 44 (4): 635-652.

Egan, Patrick J. 2013. Partisan Priorities: How Issue Ownership Drives and Distorts American Politics. Cambridge: Cambridge University Press.

Evans, Geoffrey, and Robert Andersen. 2006. The political conditioning of economic perceptions. Journal of Politics 68 (1): 194-207.

Fearon, James D. 1999. Electoral accountability and the control of politicians: selecting good types versus sanctioning poor performance. In Democracy, Accountability, and Representation, ed. Adam Przeworski, Bernard Manin, and Susan C. Stokes, 55-97. Cambridge: Cambridge University Press.

Fiorina, Morris P. 1981. Retrospective Voting in American National Elections. New Haven, CT: Yale University Press.

Green, Jane, and Sara B. Hobolt. 2008. Owning the issue agenda: Party strategies and vote choices in British elections. Electoral Studies 27 (3): 460-476.

Green-Pedersen, Christoffer. 2007. The growing importance of issue competition: The changing nature of party competition in Western Europe. Political Studies 55 (3): 607-628.

Hansen, Kasper M., Asmus L. Olsen, and Mickael Bech. 2016. Cross-national yardstick comparisons: A choice experiment on a forgotten voter heuristic. Political Behavior 37 (4): 767-789.

Healy, Andrew, and Neil Malhotra. 2013. Retrospective voting reconsidered. Annual Review of Political Science 16: 285-306. 
Hobolt, Sara B., James Tilley, and Susan A. Banducci. 2013. Clarity of responsibility: How government cohesions conditions performance voting. European Journal of Political Research 52 (2): 164-187.

Holian, David B. 2004. 'He's stealing my issues! Clinton's crime rhetoric and the dynamics of issue ownership'. Political Behavior 26 (2): 95-124.

Huber, Gregory A., Seth J. Hill, and Gabriel S. Lenz. 2012. 'Sources of bias in retrospective decision making: experimental evidence on voters limitations in controlling incumbents'. American Political Science Review 106 (4): 720-741.

Kayser, Mark Andreas, and Michael Peress. 2012. Benchmarking across borders: electoral accountability and the necessity of comparison. American Political Science Review 106 (3): 661-684.

Key, V.O. 1966. The Responsible Electorate. Cambridge: Harvard University Press.

Kramer, Gerald H. 1971. Short-term fluctuations in U.S. voting behavior 1896-1964. American Political Science Review 65 (1): 131-143.

Kritzinger, Sylvia, David Johann, Julian Aichholzer, Konstantin Glinitzer, Christian Glantschnigg, Kathrin Thomas, Markus Wagner, and Eva Zeglovits (2016). AUTNES Rolling Cross-Section Panel Study, Edition 2.0.

Kritzinger, Sylvia, Eva Zeglovits, Michael S. Lewis-Beck, and Richard Nadeau. 2013. The Austrian Voter. Vienna: V\&R unipress.

Lachat, Romain. 2014. Issue ownership and the vote: The effects of associative and competence ownership on issue voting. Swiss Political Science Review 20 (4): 727-740.

Lewis-Beck, Michael S. 1991. Introduction. In Economics and Politics: The Calculus of Support, ed. Helmut Norpoth, Michael S. Lewis-Beck, and Jean-Dominique Lafay, 1-8. Ann Arbor: University of Michigan Press.

Lewis-Beck, Michael S., and Mary Stegmaier. 2000. Economic determinants of electoral outcomes. Annual Review of Political Science 3: 183-219.

Lewis-Beck, Michael S., and Mary Stegmaier. 2007. Economic models of voting. In The Oxford Handbook of Political Behavior, ed. Russell J. Dalton, and Hans-Dieter Klingemann, 518-537. Oxford: Oxford University Press.

Mair, Peter, Wolfgang C. Müller, and Fritz Plasser (eds.). 1999. Parteien auf komplexen Wählermärkten. Strategische Reaktionen von politischen Parteien auf die Erosion von Wählerloyalitäten. Vienna: Signum.

Malhotra, Neil, and Yotam Margalit. 2014. Expectation setting and retrospective voting. The Journal of Politics 76 (4): 1000-1016.

Martinsson, Johan. 2009. Economic Voting and Issue Ownership: An Integrative Approach. Gothenburg: University of Gothenburg, Department of Political Science.

Meyer, Thomas M., and Wolfgang C. Müller. 2013. The issue agenda, party competence and popularity: An empirical analysis of Austria 1989-2004. Journal of Elections, Public Opinion \& Parties 23 (4): 484-500.

Mondak, Jeffery J. 1993. Source cues and policy approval: The cognitive dynamics of public support for the Reagan agenda. American Journal of Political Science 37 (1): 186-212.

Mueller, John E. 1970. Presidential Popularity from Truman to Johnson. American Political Science Review 64 (1): 18-34.

Nadeau, Richard, Richard G. Niemi, and Antoine Yoshinaka. 2002. A cross-national analysis of economic voting: taking account of the political context across time and nations. Electoral Studies 21 (3): 403-423.

Nannestad, Peter, and Martin Paldam. 1997. The grievance asymmetry revisited. A micro study of economic voting in Denmark, 1986-1992. European Journal of Political Economy 13 (1): 81-99.

Nannestad, Peter, and Martin Paldam. 2002. The cost of ruling. A foundation stone for two theories. In Economic Voting, ed. Han Dorussen, Harvey D. Palmer, and Michael Taylor, 17-44. New York: Routledge.

Narud, Hanne M., and Henry Valen. 2008. Coalition membership and electoral performance. In Cabinets and Coalition Bargaining: The Democratic Life Cycle in Western Europe, ed. Kaare Strøm, Wolfgang C. Müller, and Torbjörn Bergman, 369-402. Oxford: Oxford University Press.

Neundorf, Anja, and James Adams (2016). 'The micro-foundation of party competition and issue ownership: The reciprocal effects of citizens' issue salience and party attachments', British Journal of Political Science, forthcoming.

Palmer, Harvey D., and Guy D. Whitten. 1999. The electoral impact of unexpected inflation and economic growth. British Journal of Political Science 29 (4): 623-639. 
Parker, Glenn R. 1986. Economic partisan advantages in congressional contests: 1938-1978. The Public Opinion Quarterly 50 (3): 387-401.

Petrocik, John R. 1996. Issue ownership in presidential elections, with a 1980 case study. American Journal of Political Science 40 (3): 825-850.

Plescia, Carolina. forthcoming. Portfolio-specific accountability and retrospective voting: The case of Italy. Italian Political Science Review.

Plescia, Carolina, and Sylvia Kritzinger. 2016. Retrospective voting and party support at elections: Credit and blame for government and opposition. Journal of Elections, Public Opinion and Parties. doi:10. 1080/17457289.2016.1243543.

Powell, G.Bingham, and Guy D. Whitten. 1993. A cross-national analysis of economic voting: Taking account of the political context. American Journal of Political Science 37 (2): 391-414.

Seeberg, Henrik B. (2015). 'Party issue emphasis and issue ownership: How incumbency matters', unpublished paper, University of Aarhus.

Singer, Matthew M. 2011. 'Who says 'It's the Economy'? Cross-national and cross-individual variation in the salience of economic performance'. Comparative Political Studies 44 (3): 284-312.

Slothuus, Rune, and Claes H. de Vreese. 2010. Political parties, motivated reasoning, and issue framing effects. The Journal of Politics 72 (3): 630-645.

Stokes, Donald E. 1963. Spatial models of party competition. The American Political Science Review 57 (2): $368-377$.

Stubager, Rune, and Rune Slothuus. 2013. 'What are the sources of political parties' issue ownership? Testing Four Explanations at the Individual Level'. Political Behavior 35 (3): 567-588.

Tresch, Anke, Pascal Sciarini, and Frédéric Varone. 2013. The relationship between media and political agendas: Variations across decision-making phases. West European Politics 36 (5): 897-918.

Van der Brug, Wouter. 2004. Issue ownership and party choice. Electoral Studies 23 (2): 209-233.

Van der Brug, Wouter, Cees Van Van der Eijk, and Mark Franklin. 2007. The Economy and the Vote. Cambridge: Cambridge University Press.

Vavreck, Lynn. 2009. The Message Matters: The Economy and Presidential Campaigns. Princeton, NJ: Princeton University Press.

Wagner, Markus, and Eva Zeglovits. 2014. Survey questions about party competence: Insights from cognitive interviews. Electoral Studies 34: 280-290.

Wagner, Markus, and Thomas M. Meyer. 2014. 'Which issues do parties emphasise? Salience strategies and party organisation in multiparty systems'. West European Politics 37 (5): 1019-1045.

Wagner, Markus, and Thomas M. Meyer. 2015. Negative issue ownership. West European Politics 38 (4): 797-816.

Walgrave, Stefaan, and Knut De Swert. 2007. Where does issue ownership come from? From the party or from the media? Issue-party identifications in Belgium, 1991-2005. The Harvard International Journal of Press/Politics 12 (1): 37-67.

Walgrave, Stefaan, Anke Tresch, and Jonas Lefevere. 2015. The conceptualisation and measurement of issue ownership. West European Politics 38 (4): 778-796.

Walgrave, Stefaan, Jonas Lefevere, and Anke Tresch. 2012. The associative dimension of issue ownership. Public Opinion Quarterly 76 (4): 771-782.

Walgrave, Stefaan, Jonas Lefevere, and Michiel Nuytemans. 2009. issue ownership stability and change: How political parties claim and maintain issues through media appearances. Political Communication 26 (2): 153-172.

Wilkin, Sam, Bradon Haller, and Helmut Norpoth. 1997. From Argentina to Zambia: a world-wide test of economic voting. Electoral Studies 16 (3): 301-316.

Williams, Laron K., Mary Stegmaier, and Marc Debus (2015). 'Relaxing the Constant Economic Vote Restriction Economic evaluations and party support in Germany', Party Politics. forthcoming.

Winkler, Anna K., and Katrin Praprotnik (2015). 'Parties' Answers to Voter Dealignment: The Record', unpublished, University of Vienna. 